\title{
Strategi Pemberdayaan Masyarakat Pelaku UMKM Di Masa Pandemi Covid-19
}

\author{
Indah Andayani \\ Pascasarjana Pendidikan Luar Sekolah, Universitas Negeri Surabaya \\ indahandayani.19006@mhs.unesa.ac.id \\ Maria Veronika Roesminingsih \\ Pascasarjana Pendidikan Luar Sekolah, Universitas Negeri Surabaya \\ roesminingsih@.unesa.ac.id \\ Wiwin Yulianingsih \\ Pascasarjana Pendidikan Luar Sekolah, Universitas Negeri Surabaya \\ wiwinyulianingsih@unesa.ac.id
}

\begin{abstract}
Abstrak
Pelaku UMKM mengalami penurunan pendapatan dengan adanya pandemi Covid-19. Penurunan daya beli konsumen dari sektor pemasaran tradisional dengan penutupan sektor pariwisata merupakan tantangan pelaku UMKM dalam menjalankan produksi usaha. Peluang pelaku UMKM untuk bertahan di masa pandemi adalah dengan memaksimalkan penjualan di pasar Online. Pemberdayaan masyarakat pelaku UMKM dalam mencoba pasar Online perlu dilakukan atau pilihan lain dengan memberdayakan pelaku UMKM pada produk yang paling dibutuhkan di masa pandemi seperti, masker dan hand sanitizer. Tujuan penelitian untuk mendapatkan model pemberdayaan yang paling dibutuhkan pelaku UMKM di masa pandemi covid-19. Penelitian menggunakan pendekatan kualitatif dengan metode wawancara dan observasi. 18 Sampel pelaku UMKM berasal dari kabupaten Kediri dengan stratified random sampling. Tahap analisis data dimulai dari koleksi, reduksi, display, verifikasi, dan simpulan. Keabsahan data menggunakan kredibilitas, member check, dependabilitas, konfirmabilitas, dan transferabilitas. Hasil penelitian menggambarkan bahwa beberapa kendala yang dialami pelaku UMKM kabupaten Kediri terletak pada proses pemasaran produk, sehingga strategi pemberdayaan yang paling dibutuhkan para pelaku UMKM adalah pemberdayaan pemasaran produk secara online melalui platform market digital dan dapat melalui strategi pemberdayaan inovasi produk UMKM untuk beralih pada produk yang paling dibutuhkan (masker, hand sanitizer).
\end{abstract}

Kata Kunci : Pemberdayaan masyarakat, pelaku UMKM, pandemi Covid-19

\begin{abstract}
UMKMs players have experienced a decline in income due to the Covid-19 pandemic. The decline in consumer purchasing power from the traditional marketing sector with the closure of the tourism sector is a challenge for UMKMs players in carrying out business production. The opportunity for UMKMs players to survive during a pandemic is to maximize sales in the online market. Empowerment of the community of UMKMs players in trying the online market needs to be done or another option by empowering UMKMs players in the products most needed during a pandemic such as masks and hand sanitizers. The research objective is to find the empowerment model most needed by UMKMs actors during the Covid-19 pandemic. This research used a qualitative approach with interview and observation methods. 18 The sample of UMKMs actors came from Kediri district with stratified random sampling. The data analysis stage starts from collection, reduction, display, verification, and conclusion. Data validity uses credibility, member check, dependability, confirmability, and transferability. The results of the study illustrate that some of the obstacles experienced by UMKMs players in Kediri district lie in the product marketing process, so that the empowerment strategy most needed by UMKMs players is the empowerment of online product marketing through digital market platforms and through the strategy of empowering UMKMs product innovation to switch to products most needed (masks, hand sanitizers)

Keywords: Community Empowerment, UMKMs actors, Covid-19 pandemic
\end{abstract}




\section{PENDAHULUAN}

Pandemi Covid-19 memberikan dampak buruk pada keberlangsungan kehidupan ekonomi Indonesia, khususnya bagi pelaku UMKM. Penelitian Thaha (2020) melaporkan bahwa 163.713 pelaku UMKM pada sektor makanan dan minuman terkena dampak pandemi Covid-19. Hasil laporan penelitian tersebut ditambah dengan data Kemenkop UMKM yang melaporkan bahwa $56 \%$ pelaku UMKM mengalami penurunan penjualan, $22 \%$ pada aspek pembiayaan, $15 \%$ pada aspek distribusi barang, dan 4\% mengalami kesulitan mendapatkan bahan baku mentah. Laporan ini merupakan hal serius, mengingat kontribusi UMKM sangat strategis bagi perekonomian Indonesia. Data dari penelitian Amri (2020) yang diambil dari Kemenkop dan UMKM, (2018) menunjukkan bahwa jumlah UMKM mencapai 62,9 juta yang menyerap $97 \%$ tenaga kerja dengan $89 \%$ di antaranya pada sektor mikro. Selain itu, UMKM berhasil menyumbangkan $60 \%$ produk domestik bruto ekonomi nasional. Data penelitian Soetjipto (2020) menunjukkan bahwa $75 \%$ mengalami dampak penurunan penjualan, $51 \%$ pelaku UMKM hanya mampu bertahan 1-3 bulan, 67\% menginginkan adanya dana darurat, dan hanya 13\% pelaku UMKM yakin menghadapi situasi pandemi.

Penelitian Soetjipto (2020) menjelaskan mengenai penyebab penurunan omzet pelaku UMKM, yang meliputi $63 \%$ disebabkan oleh daya beli konsumen menurun, $46 \%$ konsumen takut membeli disertai adanya aturan PSBB, dan $42 \%$ adanya aturan jam operasional toko. Dampak dari penurunan omzet, $33 \%$ pelaku UMKM memilih menghentikan produksi, $19 \%$ menghabiskan stok barang yang dikembalikan, 8\% melakukan produksi ketika ada pesanan, dan $27 \%$ membuka dagangan dengan protokol kesehatan yang ketat. Usaha pelaku UMKM dalam menyiasati situasi pandemi, yaitu $38 \%$ melakukan pemasaran melalui media sosial, $35 \%$ menggunakan promosi berbayar yang telah tersedia secara Online, $13 \%$ menitipkan produk secara konvensional dan 6\% tetap membuka tempat jualan (Soetjipto, 2020). Hasil data dari survei penelitian tersebut memberikan gambaran kendala dan peluang penyelesaian masalah bagi pelaku UMKM pada situasi pandemi. Adanya kebijakan jaga jarak dan tetap di rumah membuat pasar konvensional sepi peminat, sehingga terjadi peningkatan pada pasar digital. Peluang tersebut dimanfaatkan pelaku UMKM untuk memasarkan produknya melalui pasar digital.

Strategi pelaku UMKM dalam menghadapi situasi pandemi Covid-19 diduga dapat dilakukan melalui pemasaran produk secara Online. Kendala strategi tersebut adalah pelaku UMKM yang belum memahami cara pemasaran produk secara digital, mulai dari pemfotoan, perancangan iklan, hingga publikasi produk di platform digital. Dampak strategi tersebut menghasilkan penghematan luar biasa pada sektor produksi, distribusi, dan pemasaran konvensional. Proses pemasaran secara Online memungkinkan produksi pelaku UMKM hanya berorientasi pada pesanan, sehingga mengurangi jumlah tenaga kerja yang dibutuhkan pada saat produksi hingga proses distribusi. Selain itu, pasar Online melonggarkan pelaku UMKM dalam membuka tempat pemasaran, sehingga tidak terbebani uang sewa tempat. Penelitian Hardilawati (2020) menunjukkan strategi bertahan UMKM di tengah Pandemi Covid-19 yang meliputi rekomendasi untuk melakukan perdagangan secara e-commerce, melakukan pemasaran secara digital, perbaikan kualitas produk, penambahan pelayanan konsumen, dan optimalisasi hubungan pemasaran pelanggan.

Penelitian menggunakan pendekatan studi kasus dengan titik kasus pada pelaku UMKM kabupaten Kediri. Penelitian berusaha memberikan gambaran permasalahan dan solusi 
yang tengah dialami melalui program pemberdayaan pelaku UMKM kabupaten Kediri di tengah pandemi Covid-19. Fauji (2020) menjelaskan karakteristik pelaku UMKM di kabupaten Kediri yang meliputi kemampuan sumber pendanaan usaha masih rendah, memiliki jiwa wirausaha dengan sifat tekun, produktif, dan inovasi berpikir masih mendasar, sehingga masih berfokus pada kegiatan usaha yang bersifat rutinitas. Hal ini menunjukkan bahwa karakteristik pelaku UMKM di kabupaten Kediri dalam menghadapi situasi pandemi masih bertahan pada pasar konvensional dengan resiko penurunan omzet jual produk. Gambaran permasalahan dengan solusi yang ditawarkan, ditambah dengan karakteristik pelaku UMKM kabupaten Kediri memberikan ruang pada pegiat non formal untuk memberikan pengetahuan dan pengabdian long life learning bagi pelaku UMKM melalui usulan program pemberdayaan.

Pemberdayaan masyarakat bagi pelaku UMKM di kabupaten Kediri merupakan respons dari permasalahan yang dihadapi dalam usaha untuk meningkatkan kembali omzet penjualan di tengah pandemi Covid-19. Program pemberdayaan diharapkan mampu meningkatkan keberdayaan pelaku UMKM dalam menghadapi situasi pasar digital. Penelitian Widjajanti (2011) mengungkapkan bahwa proses keberdayaan membutuhkan modal fisik dan manusia. Hal ini menggambarkan bahwa pada situasi pandemi menuntut manusia (pelaku UMKM) untuk mengembangkan modal fisik (produk UMKM). Penelitian tersebut memberikan temuan bahwa modal manusia dalam hal ini adalah pelaku UMKM memainkan peran penting dalam proses pengambilan keputusan untuk bertahan dengan produk awal dengan pasar digital atau beralih pada produk lain yang dibutuhkan pada situasi pandemi Covid-19.

Berdasarkan permasalahan yang terjadi pada pelaku UMKM di kabupaten Kediri, perlu dilakukan penelitian mengenai model pemberdayaan yang paling dibutuhkan pelaku UMKM di masa pandemi Covid-19. Peneliti berasumsi bahwa penelitian tersebut belum pernah dilakukan dengan tingginya kebermanfaatan hasil penelitian bagi pelaku UMKM pada kabupaten Kediri.

\section{METODE}

Penelitian merupakan penelitian kualitatif menggunakan pendekatan studi kasus dengan metode observasi dan wawancara. Tujuan penelitian untuk mendapatkan strategi pemberdayaan pelaku UMKM yang paling dibutuhkan di masa pandemi Covid-19. 18 sampel dipilih melalui stratified random sampling pada pelaku UMKM kabupaten Kediri. Hasil analisis penelitian dimulai dari koleksi data, reduksi, display, verifikasi, dan simpulan. Hasil proses wawancara dan observasi dijabarkan melalui teks narasi hingga didapatkan sebuah kesimpulan. Proses keabsahan data meliputi kredibilitas, member check, dependabilitas, konfirmabilitas, dan transferabilitas.

\section{HASIL}

Hasil penelitian diawali dengan data jenis UMKM yang terdapat di kabupaten Kediri. Data tersebut diperoleh melalui laman resmi dinas koperasi dan usaha mikro kabupaten Kediri pada September 2019.

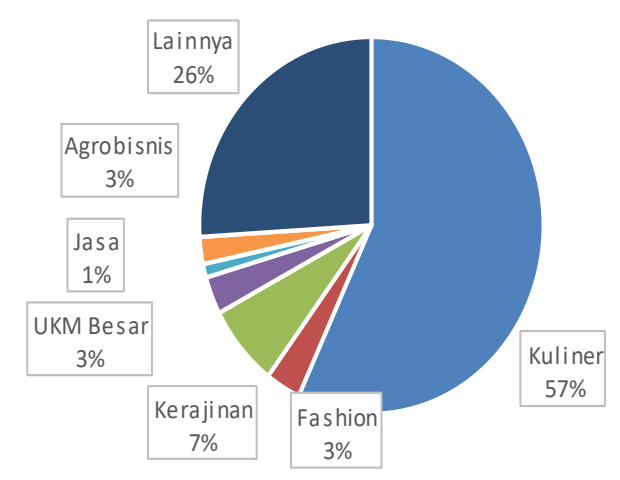

Gambar 1. Sebaran UMKM kabupaten Kediri (Sumber: Dinas koperasi dan usaha mikro, September 2019) 
Gambar 1 menunjukkan bahwa pelaku UMKM kabupaten Kediri terdiri dari sektor kuliner, fashion, kerajinan, jasa, agrobisnis, UKM besar, dan lainnya dengan 57\% dominasi UMKM sektor kuliner

Proses wawancara dilakukan dengan mengujungi tempat pelaku UMKM, berbicara santai perihal dampak pandemi covid-19 hingga strategi yang ditempuhnya dalam meningkatkan omzet penjualan sambil mengikuti proses produksi. Sebelum teks naratif hasil wawancara disajikan, berikut adalah karakteristik sampel penelitian yang diambil dari teknik snowball sampling.

$1.22 \%$ sampel berjenis kelamin laki-laki dan $78 \%$ sampel berjenis kelamin perempuan.

$2.44 \%$ sampel berusia kurang dari 35 tahun dan $66 \%$ sampel berusia lebih dari 35 tahun.

3. $16,7 \%$ sampel memiliki pendidikan SMP, $38,9 \%$ SMA, 27,8\% Diploma/ S1, dan 16,7\% berijazah $\mathrm{S} 2$.

4. 84\% sampel memiliki usaha bidang kuliner dan sisanya pada bidang pendidikan, otomotif, dan agrobisnis.

5. 16,6\% sampel telah berwirausaha selama lebih dari 5 tahun dan $83,4 \%$ kurang dari 5 tahun.

6. 16,3\% sampel memiliki karyawan lebih dari 5 orang dan $83,7 \%$ memiliki karyawan kurang dari 5 orang

7. $100 \%$ sampel memiliki ponsel android dengan $80 \%$ android yang dimiliki adalah smartphone tipe terbaru

Persentase karakteristik pelaku UMKM di atas menggambarkan bahwa sampel yang mengikuti penelitian ini berasal dari pelaku UMKM kecil dengan mayoritas pada bidang usaha kuliner. Karakteristik tersebut sesuai dengan data yang dikeluarkan dinas koperasi dan UMKM kabupaten Kediri yang menempatkan bidang kuliner menjadi sektor UMKM yang paling diminati. Hal ini menunjukkan bahwa penelitian ini mampu mewakili data keseluruhan UMKM terkait model pemberdayaan pelaku UMKM yang diinginkan.

Hasil penelitian disajikan data kualitatif dari proses wawancara berupa teks naratif terkait kondisi dan permasalahan yang dihadapi sampel di masa pandemi Covid-19, yang meliputi:

\section{Kondisi pemasaran produk pelaku UMKM}

Pelaku UMKM kabupaten Kediri menjual produk mereka pada tempat-tempat wisata, toko tertentu, hingga warung di setiap desa. Hal ini menunjukkan bahwa sistem pemasaran produk mereka masih mengandalkan sistem konvensional. Situasi pandemi mengakibatkan penutupan beberapa tempat wisata akibat dari kebijakan jaga jarak dan tetap di rumah. Hal tersebut mengakibatkan proses produksi dan distribusi ke beberapa tempat menjadi berhenti, sehingga berpotensi menurunkan omzet penjualan. Mereka mengaku sebagai produsen dari sebuah produk tidak bisa menjangkau permintaan konsumen, kecuali adanya penghubung (agen) yang bersifat reseller. Hal ini menunjukkan bahwa permintaan produksi dari sebuah produk berdasarkan adanya permintaan yang dibawa oleh agen ke tempat produksinya.

1. Penurunan omzet penjualan produk

Pelaku UMKM kabupaten Kediri mengalami penurunan omzet penjualan bahkan ada yang mengalami kerugian. Mereka mengaku mengalami penurunan hingga lebih dari $70 \%$ di situasi pandemi covid-19. Kerugian timbul karena produk yang dihasilkan memiliki batas waktu edar, sehingga apabila melebihi batas waktu tersebut, produk tersebut dilakukan pembuangan.

2. Upaya menghadapi situasi pandemi Covid-19

Strategi pelaku UMKM Kabupaten Kediri dalam menghadapi situasi pasar konvensional yang sepi ditambah dengan 
menurunnya omzet penjualan dilakukan dengan cara yang berbeda-beda. Ada yang mengaku menggunakan metode penjualan door to door, ada yang mengandalkan penjualan toko secara fisik di tempat tertentu, ada yang membuka agen, menitipkan produk di market place,dan bahkan ada juga yang mencoba peruntungan berjualan di media sosial. Mayoritas sampel mengaku tertarik mencoba berjualan secara Online disertai dengan adanya toko offline. Hal ini menunjukkan bahwa pelaku UMKM kabupaten Kediri memiliki semangat untuk tetap bertahan berusaha di masa pandemi Covid-19.

Ada dua pilihan yang dipertimbangkan oleh masing-masing pelaku UMKM. Pilihan pertama adalah tetap bertahan dengan produk yang telah digeluti selama ini dengan memanfaatkan pasar digital dan diimbangi dengan penjualan secara konvensional. Pilihan kedua adalah tetap bertahan dengan produk yang telah digeluti, namun mempertimbangkan membuat produk baru yang paling dibutuhkan pasar di masa pandemi seperti: masker dan hand sanitizer. Mereka mengaku dua pilihan tersebut memiliki dampak yang berbeda dengan peluang yang seimbang. Pilihan pertama memungkinkan pelaku UMKM untuk belajar pemasaran digital sehingga dengan berjalannya waktu mereka mampu belajar dan merencanakan bagaimana penjualan mereka meningkat. Hal ini memberikan keuntungan jangka panjang bagi pelaku UMKM karena kebutuhan pemasaran produk UMKM secara digital sangat menjanjikan. Dampak pilihan pertama bagi pelaku UMKM adalah kesabaran dalam belajar pemasaran digital dan pemasukan omzet sedikit karena bergantung pada pasar konvensional. Pilihan kedua memungkinkan pelaku UMKM memiliki peningkatan pendapatan, terlebih mereka menjual barang yang sangat dibutuhkan di masa pandemi Covid-19. Namun terjadi persaingan usaha yang ketat, terlebih keputusan membuat produk baru juga membutuhkan modal yang besar.

Ketika mereka disuruh memilih strategi pilihan pertama atau kedua, mayoritas lebih memilih pilihan pertama. Mereka mengakui bahwa pilihan pertama tidak memberikan resiko yang besar, seperti tidak ada tambahan modal usaha dan persaingan produk, sehingga dengan pilihan tersebut, pelaku UMKM membuktikan keseriusan untuk belajar pemasaran produk secara digital ketimbang memanfaatkan produk yang bersifat aji mumpung.

3. Model pemberdayaan bagi pelaku UMKM Kediri

Program pemberdayaan diusulkan oleh peneliti sebagai tindak lanjut dari permasalahan dan potensi strategi yang efektif bagi pelaku UMKM menghadapi masa pandemi Covid-19. Pelaku UMKM meyakini bahwa pemasaran secara digital dapat membantu meningkatkan omzet penjualan pasar secara konvensional di tengah situasi pandemi. Mereka mayoritas sependapat bahwa usaha untuk meningkatkan kemampuan pemasaran dapat ditempuh melalui proses pemberdayaan. Proses pemberdayaan menuntun mereka berdaya untuk selalu berjuang dan bertahan dalam kondisi yang saat ini dijalani atau kondisi yang akan dihadapi akan datang. Berdasarkan karakteristik masalah, kebutuhan, dan solusi yang ditawarkan, mereka sepakat untuk dilakukan pemberdayaan masyarakat dengan model pemberdayaan pemasaran digital (digital marketing)

\section{PEMBAHASAN}

Hasil penelitian telah menjelaskan bahwa karakteristik pelaku UMKM kabupaten kediri didominasi oleh pelaku UMKM bidang kuliner. Data tersebut sesuai dengan penelitian yang 
dilakukan Soetjipto (2020) yang menunjukkan bahwa 48\% UMKM di Jawa timur didominasi sektor kuliner. Fauji (2019) juga menyebutkan bahwa sebagian besar UMKM di Kediri bergerak dalam produksi kuliner dari pengolahan hasil pertanian. Hal ini disebabkan bahwa area penyangga sekitar Kediri termasuk wilayah penghasil komoditas pertanian, sehingga pelaku UMKM Kediri memanfaatkan peluang tersebut. Berdasarkan data yang menyebutkan bahwa dominasi UMKM Kediri adalah kuliner maka $84 \%$ sampel yang dipilih berasal dari pelaku UMKM bidang kuliner.

Narasi hasil wawancara meliputi kondisi pemasaran produk di tengah pandemi, penurunan omzet penjualan, upaya menghadapi situasi pandemi Covid-19 dengan model pemberdayaan yang tengah dibutuhkan pada situasi tersebut. Kondisi yang dialami pelaku UMKM Kediri memiliki kesamaan pada pelaku UMKM di Bangkalan. Penelitian Syaiful (2020) menjelaskan bahwa pelaku UMKM Bangkalan yang memiliki usaha minuman Kamsia Boba mengalami penurunan omzet penjualan, sehingga menuntut pelaku usaha tersebut menerapkan strategi pemasaran dengan memanfaatkan media sosial seperti whatsapp, instagram, twitter, dan facebook dengan mengandalkan promosi pesan antar di setiap minimal pembelian. Hasil strategi tersebut memberikan selisih omzet penjualan berkurang hanya $17,7 \%$ dari yang semula $82,3 \%$ di masa sebelum pandemi. Keberhasilan strategi pelaku UMKM untuk tetap bertahan dan mendapatkan omzet penjualan bergantung pada identifikasi masalah penjualan yang dihadapi agar strategi tersebut tepat dan efektif. Herawati (2020) menunjukkan permasalahan UMKM dan potensi ancamannya yang meliputi: UMKM belum memiliki jaringan pemasaran, modal dari kemampuan pribadi, berjalan mandiri tanpa dukungan dinas terkait, sarana produksi masih manual, banyaknya pesaing Usaha dengan produk yang sama, situasi pandemi wabah penyakit, dan globalisasi pasar. Permasalahan utama yang dihadapi pelaku UMKM saat ini adalah adanya pandemi Covid-19.

Upaya untuk mengurangi dampak dari permasalahan pelaku UMKM di tengah pandemi Covid-19 adalah dengan memanfaatkan pasar digital. Hardilawati (2020) menunjukkan bahwa strategi bertahan UMKM di tengah Pandemi Covid-19 adalah memanfaatkan aplikasi pemasaran e-commerce, digital marketing, memperbaiki kualitas produk dan pelayanan, dan pemanfaatan customer relationship marketing, Penggunaan aplikasi $e$ commerce memiliki pengaruh yang signifikan terhadap peningkatan kinerja UMKM (Ningtyas, 2015; Hanum, 2017) dan pendapatan pelaku UMKM (Helmalia, 2018; Setyorini., et al. 2019). Aplikasi yang dapat digunakan pelaku UMKM dalam menjual produknya meliputi shoppe, lazada, tokopedia, JD.ID, bukalapak, ojek, OLX, dll. Penggunaan digital marketing dengan memanfaatkan media sosial seperti whatsapp, instagram, facebook, twitter memberikan pengaruh positif pada peningkatan penjualan produk. Bentuk pemasaran produk dapat dilakukan melalui publikasi video dan foto produk di akun media sosial secara intensif, memanfaatkan iklan adsense media sosial sehingga menjangkau konsumen sesuai kriteria yang ditentukan, melakukan promosi langsung dengan adanya give away, dan melibatkan penggunaan hasta (\#) pada label produk. Peningkatan kualitas dan layanan produk dapat ditambahkan dengan adanya jasa antar pesanan secara gratis dengan ketentuan minimal pembelian tertentu. Sedangkan pemasaran melalui jaringan pelanggan dapat diupayakan melalui agen yang melakukan penjualan berdasarkan permintaan orang tertentu (open pre order) (Hardilawati, 2020).

Hasil karakteristik pelaku UMKM kediri dengan permasalahan penjualan di tengah masa pandemi Covid-19 memberikan dorongan kepada pelaku UMKM mengadakan model 
pemberdayaan digital marketing. Penelitian Fauziyah (2020) mengungkap bahwa pelaku UMKM Kediri belum seluruhnya siap dalam menghadapi perubahan revolusi industri 4.0, terutama pada aspek marketing digital. Urgensi penjualan produk UMKM dengan memanfaatkan marketing digital sangat diperlukan mengingat kondisi pasar yang sepi di tengah pandemi Covid-19. Awali (2020) mengungkap bahwa penggunaan e-marketing melalui marketplace memberikan dampak positif pada kegiatan produksi dan distribusi selama pandemi sehingga UMKM tetap berjalan dan menghasilkan nilai ekonomi. Berdasarkan dari karakteristik modal fisik (modal pelaku UMKM) dengan memperhatikan situasi pasar di tengah pandemi, pelaku UMKM Kediri memilih model pemberdayaan digital marketing dan memanfaatkan aplikasi $e$ commerce untuk tetap berdaya dan bertahan. Model pemberdayaan digital marketing memberikan pengetahuan dan pengalaman yang berbeda pada pelaku UMKM untuk mengembangkan produk usaha dan kemampuan pemasaran produk melalui pasar digital. Penelitian Sulaksono (2020) menunjukkan bahwa pelaku UMKM desa Tales memiliki minat yang besar dalam menggunakan pemasaran melalui media sosial, karena $97 \%$ pengguna internet melakukan pencarian barang atau jasa secara Online, $90 \%$ mengunjungi toko Online, $76 \%$ melakukan transaksi melalui smartphone. Selanjutnya penelitian Samsiana, et al.(2020) menunjukkan bahwa penggunaan android dioptimalkan sebagai peluang pemasaran usaha di masa pandemi Covid-19. Hal ini menunjukkan bahwa kegiatan pemasaran digital dari mengoptimalkan penggunaan android sebagai peluang usaha dalam menjual produk barang atau jasa melalui e-commerce atau media sosial para pelaku UMKM.

Model pemberdayaan pelaku UMKM dilakukan melalu digital marketing sesuai dengan karakteristik pelaku UMKM dan situasi pandemi Covid-19. Penelitian Sutinah (2020) mendorong pelaku UMKM untuk belajar memahami pergeseran karakteristik konsumen ke arah pasar digital dengan memasarkan produk UMKM melalui teknologi digital. Penelitian Elfizon, et al (2020) membuktikan bahwa penerapan pemasaran produk melalui $e$ commerce berdampak positif terhadap pelaku industri rumah tangga. Lebih lanjut dalam penelitian tersebut mengungkap bahwa dengan memanfaatkan e-commberce dapat menjangkau konsumen lebih luas dengan promosi harga produk yang lebih rendah dalam menarik konsumen. Penelitian Wastutiningsih (2019) menunjukkan bahwa pemberdayaan masyarakat melalui digital marketing memberikan dampak peningkatan penjualan dan omzet yang diperoleh disertai dengan adanya perubahan gaya hidup ke arah konsumtif sejak mengenal dunia internet. Selanjutnya penelitian Rukmana (2020) menunjukkan strategi bersaing UMKM keripik di tengah pandemi yaitu dengan mengandalkan harga yang terjangkau, pengembangan produk, promosi, dan kecepatan distribusi produk. Sedangkan strategi bertahan dilakukan dengan penurunan harga produk agar konsumen dapat menjangkaunya. Sedangkan pada penelitian Narto (2020) menunjukkan strategi pemasaran pudak di tengah Pandemi Covid-19 dilakukan melalui promosi berbasis Online dengan pemberian diskon. Beberapa penelitian tersebut menunjukkan bahwa model pemberdayaan digital marketing memberikan dampak positif terhadap hasil penjualan produk pelaku UMKM. Situasi pandemi Covid-19 memungkinkan pelaku UMKM memanfaatkan pasar digital melalui e-commerce dan sosial media disertai dengan adanya promosi, harga yang terjangkau bagi konsumen, peningkatan produk dan jasa seperti pesan antar. 


\section{SIMPULAN}

Program pemberdayaan digital marketing menjadi pilihan strategi pemberdayaan pemasaran produk UMKM untuk bertahan di tengah pandemi Covid-19. Pemberdayaan digital marketing memberikan kesempatan pelaku UMKM dalam memulai usaha dengan sistem Online pada aplikasi perdagangan seperti Go-Food, Grab Food, Shope, Lazada, atau memanfaatkan pasar media sosial facebook, instagram dan twitter.

Perlunya pendampingan secara berkala guna mengevaluasi pelaksanaan pemasaran digital oleh pelaku UMKM hingga masa pandemi Covid-19 berakhir. Pendampingan dapat berupa bagaimana membuat iklan yang menarik atau bagaimana melakukan promosi pada pasar media sosial.

\section{DAFTAR RUJUKAN}

Amri, Andi. 2020. Dampak Covid-19 terhadap UMKM di Indonesia. Jurnal Brand. Vol. 2(1) 123-130.

Elfizon, Ganefri, dan Asrul Huda. 2020. Pemberdayaan Masyarakat dalam Pemasaran Produk Industri Rumah Tangga melalui Penerapan E-cpmmerce. Jurnal teknik elektro dan vokasional. Vol. 6(2) 237-242

Fauji, Diah Ayu Septi dan Gesty Ernestivita. 2019. Analisis Karakteristik Pelaku UMKM (Usaha Mikro Kecil Menengah) di Kota Kediri. Prosiding Seminar Nasional dan Call for Papers. 125-132.

Fauziyah. 2020. Tantangan UMKM dalam Menghadapi Revolusi Industri 4.0 ditinjau dari Aspek Marketing dan Accounting. Jurnal Manajemen dan Kewirausahaan. Vol. 5(2) 155-172.

Hanum, A. N., \& Sinarasri, A. (2017). Analisis Faktor-Faktor Yang Mempengaruhi Adopsi E Commerce Dan Pengaruhnya Terhadap Kinerja Umkm (Studi Kasus
Umkm Di Wilayah Kota Semarang). Maksimum, Vol. 1(No. 1), 1-15.

Hardilawati, Wan Laura. 2020. Strategi Bertahan UMKM di Tengah Pandemi Covid-19. Jurnal Akuntansi \& Ekonomika. Vol. 10(1) 89-98.

Helmalia, H., \& Afrinawati, A. (2018). Pengaruh E-Commerce Terhadap Peningkatan Pendapatan Usaha Mikro Kecil Dan Menengah Di Kota Padang. JEBI (Jurnal Ekonomi Dan Bisnis Islam), $3(2)$, 237.

https://doi.org/10.15548/jebi.v3i2.182

Herawati, L., Dayal Gustopo, dan Prima Vitasari. 2020. Identifikasi Permasalahan Penjualan dengan Metode SWOT pada UKM Gula Merah. Jurnal Teknologi dan Manajemen Industri. Vol. 6(1) 17-20

Narto dan Gatot Basuki HM. 2020. Penguatan

Strategi Pemasaran Pudak di tengah Pandemi Covid-19 untuk meningkatkan Keunggulan Bersaing Usaha Mikro Kecil Menengah Kota Gresik. Jurnal Intech. Vol. 6(1) 48-54

Ningtyas, P. K., Sunarko, B., \& Jaryono. (2015). Analisis Faktor Yang Mempengaruhi Adopsi ECommerce dan Pengaruhnya Terhadap Kinerja UMKM 95-107.

Rukmana, Arief Yanto dan Tuntun Ariadi Sukanta. 2020. Analisis Strategi Bersaing dan Bertahan pada Industri Mikro dan Kecil Panganan Keripik Kemasan di tengah Situasi Sulit Penyebaran Pandemi Covid-19. Jurnal Sains Manajemen dan Akutansi. Vol. 12 (1) 37-53

Samsiana, S., Rahmadya T. H., Anita S. S. G., Irwan R., Fata N. K., Herawati, Maiumunah, dan Benrahman. 2020. Optimasi Penggunaan Android sebagai Peluang Usaha di Masa Pandemik Covid'19. Jurnal Abdimas UBJ. Vol. 3(2) 137-148 
Setyorini, D., Nurhayati, E., \& Rosmita. (2019).

Pengaruh Transaksi Online (e-

Commerce) Terhadap Peningkatan Laba

UMKM (Studi Kasus UMKM Pengolahan

Besi Ciampea Bogor Jawa Barat). Jurnal

Mitra Manajemen (JMM Online), 3(5), 501-509.

Soetjipto, Noer. 2020. Ketahanan UMKM Jawa Timur Melintasi Pandemi Covid-19. Yogyakarta: K-Media.

Sulaksono, Juli dan Nizar Zakaria. 2020. Peranan Digital Marketing bagi Usaha Mikro, Kecil, dan Menengah (UMKM) desa Tales kabupaten Kediri. Generation Journal. Vol. 4 (1) 41-48

Sutinah, Bagong Suyanto, dan Ratna Azis P. 2020. Pemberdayaan Pelaku UMKM Merespon Pergeseran Karakteristik Konsumen di Era Digital. Jurnal Layanan Masyarakat. Vol. 4(1) 202-207

Syaiful, Fahmi Fadlillah dan Elihami Elihami. 2020. Penerapan Analisis SWOT terhadap Strategi Pemasaran Usaha Minuman Kamsia Boba Milik Abdullah di tengah Pandemi Covid-19 di Kabupaten Bangkalan. Jurnal Edukasi Nonformal. 343-359

Thaha, Abdurrahman Firdaus. 2020. Dampak Covid-19 terhadap UMKM di Indonesia. Jurnal Brand. Vol. 2(1) 147-153

Wastutiningsih, Sri Peni dan Titis Puspita Dewi. 2019. Pemberdayaan Masyarakat Berbasis Pengembangan Usaha Mikro, Kecil, dan Menengah di era Revolusi Industri 4.0. Suluh Pembangunan. Vol. 1(2) $90-96$

Widjajanti, Kesi. 2011. Model Pemberdayaan Masyarakat. Jurnal Ekonomi Pembangunan. Vol/ 12(1) 15-27. 